\title{
Renal transplantasyon sonrası gebelik: Olgu sunumu ve literatürün gözden geçirilmesi
}

\author{
Pregnancy after renal transplantation: Case presentation and review of the literature \\ Aysel Bülez ${ }^{1} \quad$ Neriman Soğukpınar $^{2} \quad{\text { Levent } \text { Akman }^{3} \quad \text { Mete Ergenoğlu }^{3} \quad \text { Özgür Yeniel }}^{3}$ \\ ${ }^{1}$ Eskişehir Osmangazi Üniversitesi Sağlık Bilimleri Fakültesi, Ebelik Bölümü, Eskişehir, Türkiye \\ ${ }^{2}$ Ege Üniversitesi Sağlık Bilimleri Fakültesi, Ebelik Bölümü, İzmir, Türkiye \\ ${ }^{3}$ Ege Üniversitesi Tıp Fakültesi, Kadın Hastalıkları ve Doğum Anabilim Dalı, İzmir, Türkiye
}

\section{Öz}

Son evre renal hastalıkta gebelik nadir bir durumdur. Renal transplantı hastalarda başarılı bir gebelik sağlanabilir ancak anne ve fetus için birçok risk mevcuttur. Bu hastaların dikkatli bir şekilde takibi yapılmalı; nefroloji, obstetrik ve neonatoloji uzmanları ile multidisipliner bir yaklaşım uygulanmalıdır. Bu yazıda, 28 yaşında 34. gebelik haftasında kontrolünde tansiyon yüksekliği saptanan 5 yıldır renal transplantlı gebe sunulmuştur. Ayrıca, renal transplantlı kadınların gebelik süreçlerine ilişkin klinik bilgiler tartışılmıştır.

Anahtar Sözcükler: Gebelik, kronik böbrek yetmezliği, renal transplantasyon.

\begin{abstract}
Pregnancy is a rare case in the end stage renal disease. A successful pregnancy can be attained on the patients with renal transplantation; however, numerous risks for the mother and the fetus exist. Those patients should be followed rigorously; and a multidisciplinary approach should be applied with the experts of nephrology, obstetric and neonatology. In this article, a 28-year-old pregnant woman, who was diagnosed with high blood pressure in the $34^{\text {th }}$ week of pregnancy and who has been a renal transplant patient for 5 years is presented. Clinical information related to pregnant women with renal transplantation was also discussed.
\end{abstract}

Keywords: Pregnancy, chronic renal failure, renal transplantation.

\section{Giriş}

Son dönem renal yetmezliği olan hastalarda renal transplantasyonu ile fertilite oranlarında artış sağlanmış ve kadınların \%12'sinde gebelik bildirilmiştir (1). Transplantasyonu yapılan gebelere ait verilerin kayıtlı olduğu bir merkez olan The National Transplantation Pregnancy Registry (NTPR) 2008 yılı verilerine göre; renal transplantasyon sonrası 787 kadının; 1.226 gebelikten 1.262'sinin doğum (ikiz ve üçüzleri içermektedir) ile gerçekleştiği bildirilmiştir (2). Bu gebelerde preeklampsi, erken doğum, düşük doğum ağırlığı, sezaryen oranlarında artış gibi sorunlar nedeniyle multidisipliner ekip yaklaşımı ile yakın takip yapılmalıdır. Makalemizde, obstetri polikliniğimizde takip edilen renal transplantasyonlu gebenin takibi ve yönetiminin sunumu ile literatürün gözden geçirilmesi amaçlandı.

Yazışma Adresi: Aysel Bülez

Eskişehir Osmangazi Üniversitesi Sağlık Bilimleri Fakültesi, Ebelik Bölümü, Eskişehir, Türkiye

Makalenin Geliş Tarihi: 07.09.2015 Kabul Tarihi: 23.11.2015

\section{Olgu Sunumu}

Son dönem renal yetmezlik nedeniyle 5 yıl önce renal transplantasyon ameliyatı olan 28 yaşında gravida 1 , parite 0 olan hasta gebeliğinin 10 . haftasında gebe polikliniğine takip için başvurmuştur. Nefroloji Bilim Dalı'nda takipli olan hasta; azatiyopirin $25 \mathrm{mg}(2 \times 1)$, takrolimus $1 \mathrm{mg}(2 \times 2)$ ve vitamin-mineral desteği kullanmaktaydı. Ayrıca ılımlı arteriyel hipertansiyon nedeniyle alfa-metildopa $250 \mathrm{mg}$ (3x1) başlanmıştı. İki yıllık evliliği olan hasta, bu süre içinde takiplerinin normal olması nedeniyle herhangi bir kontrasepsiyon yöntemi kullanmamıştı.

Antenatal takiplerinde tam kan sayımı, biyokimya değerleri, tam idrar tahlili ve kültür incelemesi, 24 saatlik idrar bakısı ve serolojik testlerinde anormallik saptanmadı. Obstetrik değerlendirmesinde, birinci ve ikinci trimester tarama testlerinde yüksek risk saptanmadı. Fetusun ultrasonografik değerlendirilmesinde anomali saptanmadı ve biyometrik ölçümleri normaldi. Gebelik takibinde renal ultrasonografik değerlendirmeler, renal fonksiyon testleri ve gestasyonel diyabet taraması normaldi. Tansiyon takipleri normal 
sınırlarda idi. Fetal biyometrik ölçümlerinde ve fetusun iyilik hali gösteren testlerde anormallik mevcut değildi.

Otuz dördüncü gebelik haftasında, arteriyel tansiyon takiplerinde yükselme (140-160/90-100 mmHg) başladı. Yirmi dört saatlik idrar bakısında $0.52 \mathrm{~g}$ proteinüri saptandı. Preeklampsi riski nedeniyle, Nefroloji kliniğinin görüşü de alınarak sezaryen ile gebelik sonlandırıldı ve 7/8 Apgar skoru ile $1700 \mathrm{~g}$ ağırlığında sağlıklı bir kız bebek doğurtuldu.

Operasyon öncesinde ve sonrası 3 gün boyunca $20 \mathrm{mg}$ metil prednizolon parenteral uygulandı. Ayrıca postpartum dönemde, antihipertansif tedavi amlodipine olarak değiştirildi, azatiyopirin ve takrolimus dozlarında değişiklik yapılmadı. İmmünsüpresyon ilaç kullanımı nedeni ile laktasyon inhibisyonu (kabergolin) yapıldı. Postpartum üçüncü günde, tansiyon arteriyel takipleri, kan biyokimyası ve tam kan sayımı normal seyreden hasta genel durumunun iyi olması sebebiyle taburcu edildi. Yenidoğan muayenelerinde doğumsal anomali tespit edilmedi, ancak prematürite nedeniyle yenidoğan bakım intiyacına gereksinim duyuldu.

Hastadan tıbbi verilerinin yayınlanabileceğine ilişkin yazılı onam belgesi alındı.

\section{Tartışma}

Transplantasyon sonrası gebelik planlaması; düşük rejeksiyon riski, immünsüpresif ajanların daha düşük dozlarda kullanılması ve stabilize renal fonksiyonun sağlanması nedeniyle transplantasyondan yaklaşık 2 sene sonra yapılmalıdır. Gebelik istemi olmayan hastalara etkili bir kontrasepsiyon yöntemi önerilmelidir. Doğumu düşünmeyen hastalarda tubal ligasyon transplantasyon sırasında düşünülebilmektedir. İntrauterin araçların koruyucu etkisi immünsüpresif ilaçların antienflamatuar etkileri nedeniyle azalabilmekte; bununla birlikte geçici kontrasepsiyon düşünen hastalarda düşük doz oral kontraseptif ajanlarla, kondomlar seçenek olabilmektedir. Kontrasepsiyon hakkında bilgilendirme transplantasyon cerrahisi öncesinde yapılmalıdır. Olgumuzda, evlendiği sırada renal transplantasyonu sonrası 3 yıl geçmesi ve normal renal fonksiyon değerleri nedeniyle modern kontrasepsiyon yöntemleri ile korunmamıştır. Gebelik isteği döneminde antihipertansif tedavisi alfa-metildopa ile değiştirilmiştir.

Lessan ve ark. (3) fonksiyonel bir greft ile ovulatuvar fonksiyonların 1-2 ayda başlayabileceğini belirtmişlerdir. Transplante hastaların gebeliklerinin yaklaşık \%25'i sonlandırılmakta ya da düşükle sonlanmaktayken, kalanların \%95'inde başarılı obstetrik sonuç gözlenmektedir (4). Enfeksiyon, preeklampsi, preterm doğum, erken membran rüptürü, intrauterin gelişme geriliği, düşük doğum ağırığı, gestasyonel diyabet ve greft reddi transplantasyon sonrası gebeliklerde görülen en sık komplikasyonlardır (5).
Renal transplantlı hastaların yarısından fazlasında arteriyel hipertansiyon görülmektedir. $\mathrm{Bu}$ hastalarda arteriyel tansiyon değerlerinde yükselmeler ve proteinüri artışı pre-eklampsi açısından uyarıcı olmalıdır. Olgumuzda da, gebelik öncesi hipertansiyon mevcuttu ve tedavisi gebelikte güvenilir olan alfa-metildopa ile devam edilmiştir. Ancak üçüncü trimesterde alfametildopa kullanımı sırasında arteriyel tansiyon değerlerinde yükselmeler ve idrar proteininde artış olmuştur.

Çelik ve ark. (6) yaptığı çalışmada; hipertansiyon, nefrotik olmayan proteinüri, gestasyonel diyabet, anemi ve üriner sistem enfeksiyonları maternal komplikasyonlar arasında sayılmaktayken medikal abortus, intrauterin gelişme geriliği, ölü doğum, preterm doğum ve düşük doğum ağırlığı fetal komplikasyonlar arasında belirtilmiştir. Canlı doğum oranı bu çalışmada \%74.2 iken; hiçbir hastada greft reddi olmamıştır. Transplantlı hastaların gebelikte yakın takibi ile sağlıklı bebekler doğabilmekte ve bu hastalarda gebelik ile birlikte greft survisi etkilenmemektedir.

Renal transplantasyonu sonrası kullanılan birçok immünsüpresif ajan gebelik kategorisi C olarak belirtilmekte iken azatiyopirin D kategorisindedir (7). Bununla birlikte azotiyopirinin yüksek dozları ile hayvanlarda teratojenik etkiler görülmekte iken renal transplantlı hastaların fetuslarında düşük doğum ağırığı, prematürite, sarılık, respiratuvar distres sendromu ve aspirasyon belirtilmiştir (8). Mikofenalat mofetil ise fetal kayıp ve yüksek doğumsal anomali riski nedeniyle kategori $C$ grubundan $D$ grubuna alınmıştır ve gebelikte kullanımı önerilmemektedir (7). Sifontis ve ark. (9) yaptığı çalışmada; mikofenalat mofetil kullanan renal transplantlı hastalarda spontan abortuslarla birlikte canlı doğumlarda hipoplastik tırnak, kısa 5. parmak, yarık damak ve dudak ile birlikte mikrotia içeren malformasyonlar gözlenmiştir. Gebelik isteği olan transplant hastalarında siklosporin ve takrolimus, kortikosteroid ve azatiyopirin ile birlikte veya tek başlarına gebelikte devam edilebileceği belirtilirken, mikofenalat gibi fetal anomali riski olan ajanlar önerilmemektedir (9). Olgumuz gebelik sırasında azatiyopirin ve takrolimus kullanmıştır. Herhangi bir fetal malformasyon izlenmemiştir. Doğum sonrası ilaçlara devam edilmiştir. Ancak yenidoğan döneminde bu ilaçların süt ile geçişinde net sonuçlar belirsizdir. Olgumuzda kabergolin ile laktasyon inhibisyonu yapılmıştır (10).

Renal transplantlı hastalar gebelik öncesi bilgilendirilmeli, gebelik takipleri nefroloji, obstetrik ve yenidoğan uzmanlarının birlikte çalıştığı merkezlerde yapılmalıdır. Hastaların gebelik takiplerinde tansiyon takibi, idrar kültürü, hemoglobin değeri, renal ve karaciğer fonksiyon testleri, serum kalsiyum ve protein analizi önerilmektedir. Başvuruda HIV, hepatit B viral 
serolojisinin değerlendirilmesi ile birlikte her trimesterde sitomegalovirüs durumunun değerlendirilmesi önerilmektedir. Bu nedenle annenin kan basıncı takibi, kan sayımı, kan biyokimya değerleri, idrar incelemesi ve idrar kültürü planlanmalı; immünsüpresyon nedeni ile sitomegalovirus, toksoplasma gibi enfeksiyon riskleri unutulmamalıdır. İntrauterin gelişme ve fetal iyilik hali değerlendirilmelidir. Vajinal doğum öncelikle tercih edilmeli, sezaryen obstetrik endikasyonlar halinde uygulanmalıdır. Sezaryene karar verildiğinde transplantasyonu gerçekleştiren ekipten görüş alınmalıdır. Gerek vaginal gerekse sezaryen doğumlar sonrasında olası enfeksiyon riskine karşı tüm hastalara profilaktik olarak antibiyotik tedavisi uygulanmalıdır. Olgumuzda preeklampsi riski nedeniyle 34. haftada sezaryen ile sonlandırılmıştır.

Sonuç olarak, renal transplantlı kadınlarda başarılı gebelik sonuçları elde edilmektedir. Transplantasyon sonrası gebelik prognozu; antepartum, intrapartum ve postpartum dönemde hekim, ebe ve hemşirenin de içinde bulunduğu disiplinler arası bir anlayış ile takip edilerek semptomların erken tanı ve tedavisiyle verilecek bakım sürecine göre belirlenmelidir. Organ bağışı, nakli ve toplumun motivasyonunu sağlamaya yönelik konuların sağlık çalışanlarının eğitim programlarında yer alması, ayrıca medyanın ilgisinin konu üzerine çekilmesi gibi düzenlemelere gidilebilir.

\section{References}

1. Yamaç K, Gürsoy R, Çakır N. Gebelik ve sistemik hastalıklar. 2002, s: 643

2. Armenti VT, Constantinescu S, Moritz MJ, Davison JM. Pregnancy after transplantation. Transplant Rev (Orlando) 2008;22(4):22340.

3. Lessan-Pezeshki M, Ghazizadeh S, Khatami MR, et al. Fertility and contraceptive issues after kidney transplantation in women. Transplant Proc 2004;36(5):1405-6.

4. Deshpande NA, James NT, Kucirka LM, et al. Pregnancy outcomes in kidney transplant recipients: A systematic review and metaanalysis. Am J Transplant 2011;11(11):2388-404.

5. Başaran O, Emiroğlu R, Seçme S, Moray G, Haberal M. Pregnancy and renal transplantation. Transplant Proc 2004;36(1):122-4.

6. Celik G, Töz H, Ertilav M, et al. Biochemical parameters, renal function, and outcome of pregnancy in kidney transplant recipient. Transplant Proc 2011;43(7):2579-83.

7. Zachariah MS, Tornatore KM, Venuto RC. Kidney transplantation and pregnancy. Curr Opin Organ Transplant 2009;14(4):386-91.

8. Lessan-Pezeshki M. Pregnancy after renal transplantation: points to consider. Nephrol Dial Transplant 2002;17(5):703-7.

9. Sifontis NM, Coscia LA, Constantinescu S, Lavelanet AF, Moritz MJ, Armenti VT. Pregnancy outcomes in solid organ transplant recipients with exposure to mycophenolate mofetil or sirolimus. Transplantation 2006;82(12):1698-702.

10. Fuchs KM, Coustan DR. Immunosuppressant therapy in pregnant organ transplant recipients. Semin Perinatol 2007;31(6):363-71. 